\title{
GAMBARAN PENGGUNAAN APD PERAWAT IGD RSI JEMURSARI SURABAYA PADA MASA PANDEMI COVID-19
}

\author{
Saraswati Dewi Karina ${ }^{1 *}$, Ratna Ayu Ratriwardhani ${ }^{1}$, Mursyidul Ibad ${ }^{1}$ \\ ${ }^{1}$ Program Studi S1 Kesehatan Masyarakat, Fakultas Kesehatan Universitas Nahdlatul Ulama Surabaya \\ *Corresponding author: saraswatidewi078.km17@student.unusa.ac.id
}

\begin{abstract}
Based on data compliance with the use and release of PPE Covid-19 pandemic for emergency room nurses during October to December 2020, the use of PPE decreased from October to November, the release of PPE decreased from November to December. This study aims identify the description of the use PPE for emergency room nurses at Jemursari Islamic Hospital. The study used quantitative descriptive design with cross sectional study approach. The research population nurses in emergency room at Jemursari Islamic Hospital, Surabaya. The sample was 32 respondents using total sampling technique. The data used reports of compliance the use and release of PPE obtained through the PPI team and data knowledge, attitudes and actions towards through distributing questionnaires to respondents using the Descriptive Statistics test. The results showed that the majority of nurses were aged $<=30$ years (75\%), with a D3 education level (63\%) and a tenure of $>4$ years (72\%). The knowledge and attitudes of emergency room nurses about the use of PPE when working are in the good category, while the behavior of most respondents in the complete category is using PPE by 62.5\%. The majority of IGD nurses at the Surabaya Islamic Hospital Jemursari are aged $<=30$ years, education level is D3 and working period is $>4$ years. Knowledge, attitudes and behavior of nurses in the good category and the majority behave completely in wearing PPE. The agency is expected to maintain training on the use of PPE, tighten supervision and reward disciplined nurses.
\end{abstract}

Keywords: Knowledge, attitude, behavior, personal protective equipment (PPE

\section{PENDAHULUAN}

Pada awal tahun 2020, muncul adanya wabah pneumonia dari Wuhan, Provinsi Hubei, China dimana wabahnya menyebar cepat ke lebih dari 190 negara dan teritori. Wabah tersebut disebabkan oleh Severe Acute Respiratory Syndrome Coronavirus-2 (SARS-CoV-2) dan diberi nama "Coronavirus Disease 2019 (COVID-19)". COVID-19 resmi diumumkan menjadi suatu kasus pandemi global oleh WHO pada tanggal 12 Maret $2020^{[1]}$.

Petugas kesehatan adalah kelompok berisiko tinggi terpapar penyakit COVID-19. Sebagai tenaga medis yang bertugas di IGD perawat IGD menjadi rentan karena kontak langsung dengan pasien. Kemudian dalam artikel penelitian oleh James RM Black di Rumah Sakit Royal Gwent di Newport, Wales, sekitar setengah dari tenaga kerja ruang gawat darurat juga telah dinyatakan positif COVID19. Diketahui bahwa petugas kesehatan asimptomatik dan pre-asimptomatik terus berpindah ke tempat kerja dimana APD mungkin tidak optimal, baik ketersediaannya, jenisnya maupun cara penggunaannya ${ }^{[2]}$.

Ketersediaan APD untuk tenaga medis saat pandemi COVID-19 semakin sulit didapat. Pada pandemi COVID-19, APD tidak hanya digunakan oleh tenaga kesehatan tetapi juga pasien dan masyarakat. Kondisi tersebut memaksa tenaga kesehatan untuk menghemat penggunaan APD, seperti melakukan pelayanan kesehatan tanpa melepas APD dengan durasi lama atau menggunakan APD seadanya ${ }^{[3]}$.
APD ini digunakan sesuai indikasinya dari tiap-tiap jenis APD ${ }^{[4]}$. Setiap ruang di rumah sakit sudah dilengkapi dengan Standar Prosedur Operasional (SOP) terkait penggunaan APD. Hasil prevelensi survei Center for Dease for Control and Prevention (CDC) pada tahun 2011 di A.S, menyatakan terdapat 722.000 kasus infeksi nosocomial akibat mengabaikan penggunaan APD [2].

Respon terhadap Pernapasan Timur Tengah Sindrom Coronavirus, diperoleh hasil bahwa penggunaan safety google dan powered airpurifying respirator (PAPR) dianggap sebagai penghalang paling tidak nyaman untuk bekerja. Survei rumah sakit perawatan tersier anak, diperoleh hasil bahwa hanya 60 responden (35\%) yang menunjukkan urutan melepas (doffing) APD yang benar sesuai rekomendasi peraturan. Institusi perawatan kesehatan harus mengadakan pelatihan berkelanjutan untuk petugas kesehatan.

Rumah Sakit Islam Jemursari Surabaya merupakan salah satu rumah sakit rujukan pasien covid-19, saat ini jumlah pasien rawat inap yang semakin bertambah dituntut untuk memberikan pelayanan yang sebaik-baiknya. Di IGD, ruang ICU maupun ruang isolasi biasa di RSI Jemursari, kini tengah full pasien Covid-19. Beberapa pasien pun harus mengantre di IGD untuk mendapatkan ruang isolasi. 77 tempat tidur termasuk ICU 4 tempat tidur, ruang isolasi semua penuh keterisiannya, rata-rata bergejala. Pasien yang datang, kebanyakan masuk kategori sedang dan berat dengan usia bervariasi, 


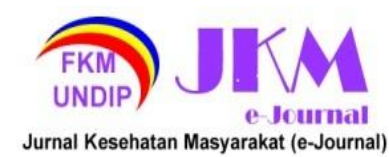

sekitar 30-70 tahun ${ }^{[5]}$. Sehingga potensi untuk risiko ternadinya kecelakaan kerja lebih tingi apabila pekerja tidak melakaukan penggunaan APD yang sesuai dengan SOP.

Berdasarkan data laporan survei kepatuhan penggunaan dan pelepasan Alat Pelindung Diri (APD) pada masa pandemi Covid-19 pada perawat IGD yang tercatat di RSI Jemursari selama bulan Oktober 2020 sampai bulan Desember 2020 Cara penggunaan APD meliputi cuci tangan/handrub sebelum menggunakan APD, penggunaan APD sesuai transmisi (kontak, droplet, airbone), penggunaan APD sesuai kebutuhan/ prosedur (sesuai risiko transmisi: darah, urin, dll) dan penggunaan APD untuk 1 prosedur/1 pasien (hand scoon). Diketahui bahwa kepatuhan penggunaan APD pada bulan Oktober sebesar 50\% selanjutnya mengalami penurunan pada bulan November menjadi $43 \%$. Memasuki bulan Desember persentase kepatuhan penggunaan APD naik menjadi $64 \%$.

Tidak hanya pada penggunaan APD, cara pelepasan APD meliputi: cuci tangan sebelum dan sesudah melepaskan APD sesuai dengan level, melepaskan APD sesuai urutan tiap level dan meletakkan APD kotor ditempat yang telah disediakan sesuai dengan jenisnya.

Kenyataan di lapangan masih banyak tenaga kesehatan yang belum secara maksimal melakukan penggunaan APD walaupun fungsinya sudah diketahui dan bahkan sudah disediakan. Hal tersebut dapat terjadi karena berbagai faktor yang mempengaruhi perilaku pekerja untuk tidak menggunakan alat pelindung diri. Oleh karena itu, peneliti merasa perlu melakukan penelitian untuk mengidentifikasi pengetahuan, sikap dan perilaku penggunaan APD pada perawat di IGD Rumah Sakit Islam Jemursari Surabaya di masa pandemi covid19.

\section{METODE PENELITIAN}

Penelitian yang dilakukan bersifat deskriptif kuantitatif. Jenis pendekatan dalam penelitian ini adalah cross sectional. Sampel dalam penelitian ini adalah seluruh perawat di bagian IGD Rumah Sakit Islam Surabaya Jemursari dengan jumlah 32.

Teknik pengambilan sampel pada penelitian ini adalah menggunakan teknik total sampling yaitu teknik pengambilan sampel yang memberi peluang/kesempatan sama baik setiap unsur atau anggota populasi untuk dipilih menjadi sampel dengan memasukkan seluruh perawat di bagian IGD Rumah Sakit Islam Jemursari Surabaya ${ }^{[6]}$.
HASIL PENELITIAN

Karakteristik Perawat

Tabel 1. Distribusi Karakteristik Responden

\begin{tabular}{lcc}
\hline $\begin{array}{c}\text { Karakteristik } \\
\text { Responden }\end{array}$ & $\begin{array}{c}\text { Frekuensi } \\
(\mathbf{n})\end{array}$ & $\begin{array}{c}\text { Persentase } \\
(\mathbf{\%})\end{array}$ \\
\hline \multirow{3}{*}{$<=30$} & Umur \\
$>30$ & 24 & 75 \\
\multicolumn{3}{c}{ Tingkat Pendidikan } \\
D3 & 20 & 25 \\
D4/S1 & 12 & 63 \\
\multicolumn{3}{c}{ Masa Kerja } \\
$>4$ & 9 & 38 \\
$>4$ & 23 & 28 \\
\hline
\end{tabular}

Sumber: Data Primer, 2021

Berdasarkan tabel 1. untuk distribusi frekuensi informasi umum yang meliputi umur, tingkat pendidikan dan masa kerja. Diketahui persentase jumlah responden berdasarkan umur responden $<=30$ tahun berjumlah $77 \%$ dan $>30$ tahun berjumlah $23 \%$. Jumlah responden berdasarkan tingkat pendidikan responden D3 berjumlah $63 \%$ dan D4/S1 berjumlah $38 \%$. diketahui bahwa masa kerja responden adalah $<=4$ tahun berjumlah $28 \%$ dan masa kerja $>4$ tahun berjumlah $72 \%$.

Tabel 2. Distribusi Perilaku Penggunaan APD

\begin{tabular}{lcc}
\hline $\begin{array}{c}\text { Karakteristik } \\
\text { Responden }\end{array}$ & Frekuensi (n) & $\begin{array}{c}\text { Persentase } \\
(\boldsymbol{\%})\end{array}$ \\
\hline Baik & Pengetahuan & \\
Cukup & 32 & 100 \\
Kurang & 0 & 0 \\
& 0 & 0 \\
Baik & Sikap & 100 \\
Kurang & 32 & 0 \\
Tidak & 0 & \\
Lengkap & Perilaku & 37,5 \\
Lengkap & 12 & 62,5 \\
\hline Sumber: Data Primer, 2021 &
\end{tabular}

Berdasarkan hasil pada tabel 2. yaitu karakteristik pengetahuan, sikap dan perilaku penggunaan APD dari keseluruhan jumlah responden $100 \%$ termasuk kedalam kategori pengetahuan baik dan sikap yang baik. Distribusi terkait perilaku penggunaan APD sebesar 20 responden $(62,5 \%)$ memakai APD secara lengkap.

Tabel 3. Analisis Hubungan antara Pengetahuan dan Perilaku

\begin{tabular}{|c|c|c|c|c|c|c|}
\hline \multirow{3}{*}{$\begin{array}{l}\text { Pengeta } \\
\text { huan }\end{array}$} & \multicolumn{4}{|c|}{ Perilaku } & \multirow{2}{*}{\multicolumn{2}{|c|}{ Total }} \\
\hline & \multicolumn{2}{|c|}{ Lengkap } & \multicolumn{2}{|c|}{$\begin{array}{c}\text { Tidak } \\
\text { Lengkap }\end{array}$} & & \\
\hline & $\mathbf{n}$ & $\%$ & n & $\%$ & $\mathbf{n}$ & $\%$ \\
\hline Baik & 20 & 62,5 & 12 & 37,5 & 32 & 100 \\
\hline Total & 20 & 62,5 & 12 & 37,5 & 32 & 100 \\
\hline
\end{tabular}




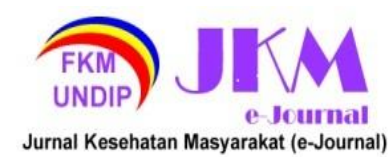

Sumber; Analisis SPSS, 2021

Berdasarkan tabel 3. dapat diketahui bahwa responden yang memiliki pengetahuan baik dan memakai alat pelindung diri secara lengkap ada sebanyak $62,5 \%$ dan ada sebanyak $37,5 \%$ responden memiliki pengetahuan baik dan tidak memakai alat pelindung diri secara lengkap.

Tabel 1. Analisis Hubungan antara Sikap dan Perilaku

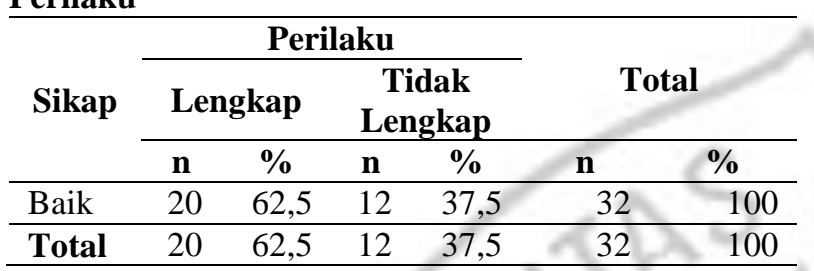

Sumber: Analisis SPSS, 2021.

Berdasarkan tabel 4. dapat diketahui bahwa responden yang memiliki sikap dengan kategori baik dan memakai alat pelindung diri secara lengkap ada sebanyak $62,5 \%$ responden dan ada sebanyak $37,5 \%$ responden memiliki pengetahuan baik dan tidak memakai alat pelindung diri secara lengkap.

Tabel 2. Analisis Hubungan antara Sikap dan Perilaku

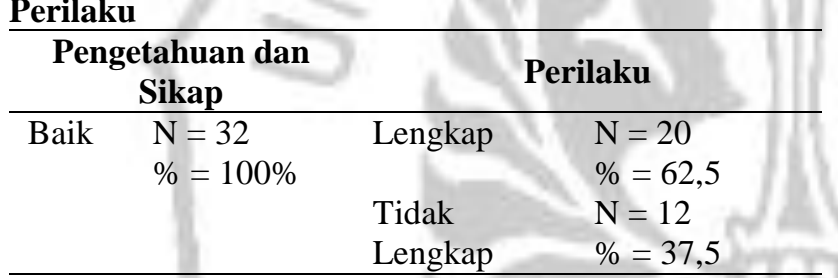

Sumber: Analisis SPSS, 2021.

Berdasarkan tabel 5. dapat diketahui bahwa semua responden memiliki pengetahuan baik dan bersikap baik. Dari semua responden yang bersikap baik, yang memiliki perilaku memakai alat pelindung diri secara lengkap ada sebanyak 37,5\% responden dan yang memiliki perilaku tidak lengkap dalam memakai alat pelindung diri ada sebanyak $62,5 \%$ responden.

\section{PEMBAHASAN} Umur

Perawat di bagian IGD Rumah Sakit Islam Surabaya Jemursari mayoritas berumur $<=30$ tahun yaitu sebanyak 24 orang (75\%). Umur paling muda perawat di bagian IGD Rumah Sakit Islam Surabaya Jemursari adalah 21 tahun dan umur tertua adalah 58 tahun.

Tingkat pendidikan

Perawat di bagian IGD Rumah Sakit Islam Surabaya Jemursari mayoritas memiliki tingkat pendidikan D3 yaitu sebanyak 20 orang (63\%).

Masa kerja

Berdasarkan hasil penelitian perawat di bagian IGD Rumah Sakit Islam Surabaya Jemursari dengan masa kerja terbanyak yaitu $<=4$ tahun yaitu sebanyak 9 orang responden (22\%), dan masa kerja $>4$ tahun 23 orang responden (72\%). Diketahui bahwa masa kerja responden terendah adalah 1 tahun dan tertinggi 20 tahun. Masa kerja sangat mempengaruhi pengalaman seseorang terhadap pekerjaan dan lingkungan tempat ia bekerja, semakin lama ia bekerja semakin banyak pengalamannya ${ }^{[5]}$. Hal ini akan mempengaruhi presepsi, sikap, mengerjakan yang lebih terkontrol.

\section{Pengetahuan}

Hasil menunjukkan sebanyak 93,8\% responden mengetahui bahwa alat pelindung diri adalah alat untuk melindungi diri dari kemungkinan timbulnya kecelakan maupun penyakit akibat kerja, ada sebanyak $96,9 \%$ responden mengetahui bahwa alat pelindung diri untuk perawat meliputi seragam kerja, scort, apron, masker bedah, sarung tangan, safety boots, face shield. Semua responden mengetahui kegunaan alat pelindung diri untuk menjaga kesehatan dan keamanan kerja, sedangkan responden yang mengetahui akibat apabila tidak menggunakan APD ada sebanyak 68,8\% responden, semua responden mengetahui bahwa penggunaan APD bertujuan untuk melindungi diri dari bahaya atau kecelakaan kerja. Sebanyak 90,6\% responden mengetahui bahwa masker, sarung tangan, gaun/pakaian kerja merupakan APD yang digunakan untuk pekerjaan yang berhubungan dengan perawat. Sebanyak $96,9 \%$ responden mengetahui bahwa seharusnya alat pelindung diri digunakan pada saat memulai pekerjaan, 90,6\% responden mengetahui penggunaan APD harus sesuai dengan pekerjaan dan risiko yang ada, sebanyak $93,8 \%$ responden mengetahui risiko apabila tidak menggunakan APD ditempat kerja dan sebanyak 93,8\% mengetahui bahwa masker merupakan alat pelindung diri yang terakhir dilepas.

Dari hasil penelitian dapat diketahui bahwa semua responden memiliki pengetahuan baik dan tidak ada responden yang memiliki pengetahuan cukup dan kurang. Dari hasil kuesioner responden dengan kategori baik, responden tersebut umumnya mengetahui dengan tepat kegunaan APD yaitu untuk melindungi tubuh dari cedera dan sakit selain itu responden juga mengetahui dengan tepat bahwa menggunakan APD pada saat bekerja bertujuan untuk melindungi diri dari bahaya atau kecelakaan kerja. Dari hasil kuesioner responden juga diketahui bahwa responden tersebut tidak mengetahui dengan tepat akibatnya apabila tidak menggunakan APD yaitu sebanyak 10 orang (31,3\%). Responden tidak mengetahui bahwa akibatnya apabila tidak menggunakan APD maka pekerjaan tidak dapat dilaksanakan dengan baik karena kegunaan APD yaitu untuk melindungi tubuh dari cedera dan sakit pada saat bekerja. Hal ini bisa terjadi karena kurangnya pengetahuan dari responden tentang alat pelindung diri. Selain kurangnya pengetahuan 


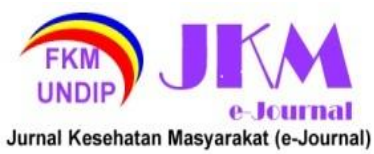

responden tentang akibatnya apabila tidak menggunakan APD, terdapat juga 2 responden $(6,3 \%)$ yang kurang memahami tentang apa yang dimaksud dengan Alat Pelindung Diri (APD), risiko apabila tidak menggunakan APD ditempat kerja dan alat pelindung diri yang terakhir dilepas. Terdapat 3 responden $(9,4 \%)$ yang kurang memahami tentang APD yang dipakai pada pekerjaan yang berhubungan dengan seperti masker, sarung tangan, gaun/pakaian kerja dan penggunaan APD harus sesuai dengan peraturan dan prosedur perusahaan serta pekerjaan dan risiko yang ada.

Persentase frekuensi pengetahuan responden menunjukkan bahwa semua responden masuk kedalam kategori baik terhadap penggunaan alat pelindung diri dalam melakukan pekerjaan. Hal ini didasari karena pada dasarnya perawat di IGD Rumah Sakit Islam Surabaya Jemursari sudah diberikan informasi oleh pihak rumah sakit melalui pelatihan dan penyuluhan tentang alat pelindung diri. Maka dapat dilihat bahwa pada perawat di IGD Rumah Sakit Islam Surabaya Jemursari telah memiliki pengetahuan yang baik mengenai alat pelindung diri dalam melakukan perawatan kepada pasien. Dalam hal ini, pengetahuan dan penggairahan keselamatan kesehatan kerja (K3) kepada tenaga kerja merupakan hal penting. Perlunya pencegahan terhadap kecelakaan dapat ditempuh dengan memberikan pengertian tentang keselamatan kerja serta penerapan sikap terhadap keselamatan kerja pada karyawan untuk mengurangi dan mencegah timbulnya kecelakaan ${ }^{[7]}$. Selain itu dengan adanya upacaya peningkatan pengetahuan melalui sosialisasi diharapkan perawat mampu mengidentifikasi bahaya, menilai risiko bahaya dan selanjutnya mereka dapat melakukan tindakan pencegahan apabia terjadi bahaya ditempat kerjanya [7].

\section{Sikap}

Dari hasil penelitian didapat bahwa pada umumnya responden sangat setuju bahwa perawat di IGD rumah sakit merupakan pekerjaan yang wajib menggunakan APD (78\%) hal ini dipengaruhi oleh pengetahuan responden tentang penggunaan alat pelindung diri.

Terdapat sebanyak 1 orang responden (32\%) sangat tidak setuju bahwa perawat di IGD rumah sakit merupakan pekerjaan yang wajib menggunakan APD dan terdapat 2 orang responden yang tidak setuju untuk menghindari kontak pada benda-benda lain selain yang berhubungan dengan tindakan yang sedang dilakukan (misalnya membuka pintu selagi masih memakai sarung tangan, menulis, dan mengangkat telepon). Sebanyak 20 orang responden $(63 \%)$ sangat setuju bahwa menggunakan APD untuk melindungi dari semua potensi bahaya sewaktu bekerja. Terdapat sebanyak 21 orang responden $(66 \%)$ yang sangat setuju menggunakan APD sesuai SOP yang dibuat oleh rumah sakit. Responden sebanyak 20 orang (63\%) menyatakan sangat setuju menggunakan APD untuk mencegah risiko kecelakaan dan penyakit akibat kerja di IGD sementara ada sebanyak 25 orang ( $47 \%$ ) menyatakan setuju bahwa menggunakan masker untuk melindungi dari bahaya infeksi yang ditransmisikan melalui udara. Hal ini berarti perawat Bagian IGD Rumah Sakit Islam Surabaya Jemursari mayoritas telah mengetahui bahwa perawat di IGD rumah sakit merupakan pekerjaan yang wajib menggunakan APD.

Dari hasil penelitian yang dilakukan, diperoleh bahwa diantara responden yang tidak setuju ataupun sangat tidak setuju terdapat responden yang memiliki pengetahuan yang baik. Hal ini menunjukkan bahwa seseorang yang memiliki pengetahuan yang baik belum tentu setuju terhadap sikap yang baik pula. Semua responden memiliki sikap baik terhadap pemakaian alat pelindung diri pada saat bekerja. Maka dengan sikap yang baik ini diharapkan perilaku pemakaian alat pelindung diri akan baik nantinya.

Perilaku

Dari hasil observasi yang dilakukan, diperoleh bahwa ada 20 orang responden yang menggunakan alat pelindung diri secara lengkap yang memiliki pengetahuan dan sikap baik. Namun, responden tersebut terkadang tidak memakai scort dan melepas sarung tangan. Menurut pendapat responden yang tidak memakai alat pelindung diri secara lengkap, mereka berasalan bahwa mereka sedang tidak menangani pasien sehingga kadang mereka mengabaikan penggunaannya dan hanya menggunakan disaat perlu. Responden yang menggunakan alat pelindung diri secara lengkap menuturkan bahwa mereka sadar akan kesehatan dan keselamatan serta peraturan yang telah ditetapkan, sehingga mereka tidak ingin mengambil risiko dikemudian harinya.

Tabulasi silang antara pengetahuan, sikap terhadap perilaku penggunaan alat pelindung diri dalam bekerja dilakukan untuk mengetahui apakah responden yang memiliki pengetahuan dan sikap yang baik memiliki perilaku yang baik pula atau sebaliknya. Hasil tabulasi silang antara pengetahuan terhadap perilaku dalam penggunaan alat pelindung diri saat bekerja menunjukkan bahwa dari 32 orang responden yang berpengetahuan baik, 20 orang responden $(62,5 \%)$ yang menggunakan alat pelindung diri secara lengkap dan hanya sebanyak 12 orang responden yang memiliki pengetahuan baik yang tidak menggunakan alat pelindung diri secara lengkap. Hasil tabulasi silang antara sikap terhadap perilaku dalam penggunaan alat pelindung diri saat bekerja menunjukkan bahwa dari 32 orang responden yang memiliki sikap baik, ada sebanyak 20 orang responden yang menggunakan alat 


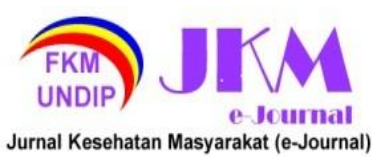

pelindung diri secara lengkap.

Hasil dari tabulasi ketiga indikator pembentuk perilaku yaitu pengetahuan, sikap dan tindakan didapat bahwa dari 32 orang responden yang berpengetahuan baik semua responden bersikap baik. dari 32 orang responden yang memiliki sikap baik, ada 20 orang yang lengkap menggunakan alat pelindung diri dalam bekerja dan 12 orang lainnya tidak menggunakan alat pelindung diri secara lengkap. Dengan demikian dapat diketahui bahwa responden yang memiliki pengetahuan baik dan sikap yang baik sebanyak 12 orang diantaranya tidak menggunakan alat pelindung diri secara lengkap.

Green juga menyatakan bahwa pengetahuan merupakan domain yang sangat penting untuk terbentuknya tindakan seseorang. Perilaku yang cenderung tidak lengkap ditampilkan oleh petugas bukan hanya dipengaruhi oleh pengetahuan, tetapi juga faktor lain. Kebiasaan menyepelekan menggunakan alat pelindung diri justru memberikan efek buruk bagi kesehatan perawat bagian IGD di Rumah Sakit Islam Surabaya Jemursari nantinya pembentukan sikap baik dan tindakan yang lengkap dapat dilakukan secara perlahan dan memberikan hasil saat dilakukan dengan disiplin.

\section{KESIMPULAN}

Berdasarkan hasil penelitian ini dapat disimpulkan bahwa pengetahuan dan sikap perawat IGD tentang penggunaan APD saat bekerja dalam kategori baik, sedangkan perilaku responden paling banyak dalam kategori lengkap memakai APD sebesar $62,5 \%$. Perawat IGD Rumah Sakit Islam Surabaya Jemursari mayoritas berumur $<=30$ tahun, tingkat pendidikan D3 dan masa kerja $>4$ tahun. Pengetahuan, sikap dan perilaku perperawat dalam kategori baik dan mayoritas berperilaku lengkap dalam memakai APD.

\section{SARAN}

Berdasarkan hasil penelitan dapat disarankan pihak instansi tetap menyediakan pelatihan kepada perawat secara bergiliran dan tetap melakukan pengawasan internal secara rutin

\section{DAFTAR PUSTAKA}

[1] Susilo A, Rumende Cm, Pitoyo Cw, Santoso Wd, Yulianti M And Sinto R, "Coronavirus Disease 2019 : Review Of Current Literatures," Jurnal Penyakit Dalam Indones, Vol. 7, No. 1, Pp. 4567, 2020.

[2] Black Jrm, Bailey C, Przewrocka J, Dijkstra Kk And Swanton C, " Covid-19: The Case For Health-Care Worker Screening To Prevent Hospital Transmission," Lancet, Vol. 395, No. 10234, Pp. 1418-2000, 2020.
[3] Ariefana P, "Dirjen Yankes: Ketersediaan Apd Sangat Terbatas," 2020. [Online]. Available: Https://Www.Suara.Com/News/2020/04/09/115 044/Dirjen-Yankes-Ketersediaan-Apd-SangatTerbatas. [Accessed 23 Mei 2021].

[4] Kementerian Kesehatan Republik Indonesia, Peraturan Menteri Kesehatan Nomor 27 Tentang Pedoman Pencegahan Dan Pengendalian Infeksi Di Fasilitas Pelayanan Kesehatan., 2017.

[5] Widyaningsih, Hubungan Faktor Predisposisi Dengan Implementasi Pemakaian Alat Pelindung Diri Pada Tenaga Kerja Di P.T Swastama Pabelan Kartasura, Surakarta: Program Diploma Iv Keselamatan Dan Kesehatan Kerja Fakultas Kedokteran Universitas Sebelas Maret Surakarta 2012, 2012.

[6] Sugiyono, Metodologi Penelitian Kombinasi, Bandung: Alfabeta, 2016.

[7] M. Sahri, R. A. Ratriwardhani, M. N. Romadhoni, N. M. N. Syufi And M. A. Yusuf, "Upaya Pencegahan Penyakit Akibat Kerja Melalui Komunikasi Risiko K3 Pada Pekerja Pelipat Kardus Di Kaliom Surabaya," Seminar Nasional Pengabdian Flipmas 2020, Vol. 1, No. 619, Pp. 593-596, 2020. 